\title{
SYNTHETIC POTENTIAL OF 9,10-ANTHRAQUINONYLDIAZONIUM
}

\section{SALTS}

\section{V. Stasevych ${ }^{1 \star}$, V. I. Zvarych ${ }^{1}$, V. P. Novikov ${ }^{1}$, M. V. Vovk ${ }^{2}$}

${ }^{1}$ Lviv Polytechnic National University, S. Bandera Str. 12, Lviv, 79013, Ukraine

${ }^{2}$ Institute of Organic Chemistry of National Academy of Sciences of Ukraine, Murmanska Str. 5, Kyiv 02660, Ukraine

*e-mail: maryna.v.stasevych@gmail.com

For the first time, the literature sources concerning the chemical transformations of diazonium salts of 1(2)-amino-9,10-anthracenediones are generalized and systematized. The potential of 9,10-dioxoanthracenyldiazonium salts as key substrates in the preparation of various linear-functionalized, acyclic and heterocyclic derivatives has been determined. The main synthetic transformations of diazonium salts of amino-9,10-anthracenediones, which are realized without preserving the azo function lead to the formation of reaction products of Sandmeyer, Meerwein, and Gomberg-Bachmann-Hay, are analyzed. The use of 9,10-dioxoanthracenyldiazonium salts or products of their transformations for obtaining heteryl-containing condensed and functionalized derivatives is presented.

Key words: diazonium salts of 1(2)-amino-9,10-anthracenedione, dediazonation, azo coupling, annulation, heterylfunctionalization.

INTRODUCTION. In modern organic synthesis diazonium salts belong to the important classes of compounds with a powerful synthetic potential, which have not lost their relevance and importance to this day due to their easy accessibility and pronounced reactivity. Their use in various synthetic transformations opens access to new types of organic compounds. In this context, diazonium salts of amino-9,10-anthracenediones play an important role in developing approaches to the synthesis of new substances with potential biological effects. At the same time, despite the diversity of the products of the arendiazonation reaction, a relatively little arsenal of derivatives was obtained on the basis of diazonium salts of amino-9,10-anthracenediones, among which diazo compounds and the products of the Sandmeyer and Meerwein reactions should be noted.

The formation of 9,10-anthracenediazonium salts occurs only in solutions of concentrated acids, which is due to the decreased basicity of the amino group of amino-9,10-anthracenediones [1]. Usually, 9,10-dioxoanthracenyldiazonium chloride is obtained in the presence of concentrated $\mathrm{HCl}$ in organic solvents $[1,2]$. However, most often in diazotization reactions, hydrosulfate and tetrafluoroborate salts 3-8 are obtained, which are more 
stable during storage and convenient in use. Diazonium hydrosulfates 3, 4 are easily formed in concentrated $\mathrm{H}_{2} \mathrm{SO}_{4}$ under the action of sodium nitrite or nitrosyl sulfuric acid [3]. When the latter interact with sodium tetrafluoroborate, they give the corresponding salts 5 and 6 [1]. In recent years, $t$-BuONO is used as an effective diazotizing agent, which makes it possible to obtain salts $7, \mathbf{8}$.
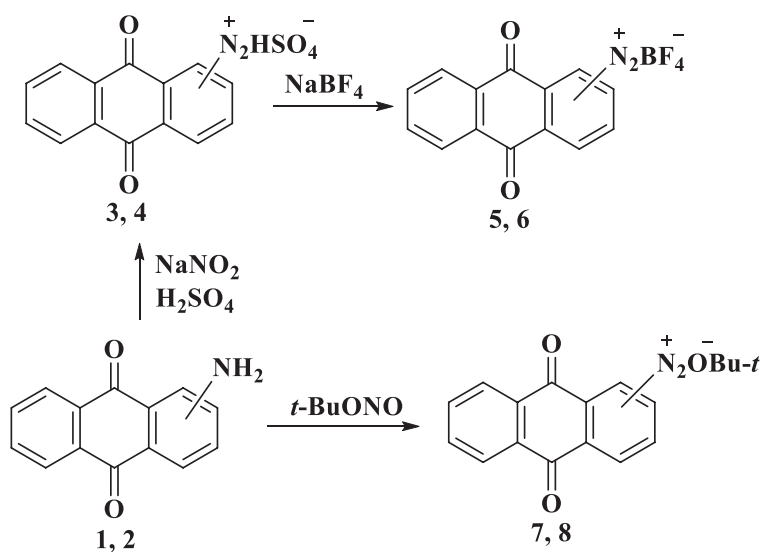

Due to the high electrophilicity of the diazonium center, which is enhanced by quinoid conjugation, salts 3-8 easily interact with nucleophilic reagents, which allows the introduction of new substituents into the anthracenedione ring and to obtain both dediazonation products and azo group derivatives.

This review focuses on the generalization and systematization of the results of original studies related to the transformation of diazonium salts of amino-9,10-anthracenediones, and the uses of diazonation reaction products to obtain various derivatives of 9,10 -anthracenedione are presented.

REACTIONS OF DEDIAZONIZATION OF 9,10-ANTHRACENYL DIAZONIUM SALTS

The authors of [3] found that the diazotization of 1(2)-aminoanthracene-9,10-diones 9 and $\mathbf{1 0}$ in dioxane using the $\mathrm{NaNO}_{2}-\mathrm{HCl}$ system leads to the products of the replacement of the diazonium group with hydrogen atom 11 and OH-group 12. The formation of the latter derivative is explained by the peri-effect of diazo and hydroxy groups, which causes the reduction process.<smiles>[X]c1ccc2c(c1)C(=O)c1ccccc1C2=O</smiles>

Deaminated methyl derivative 14 and pyrazoloanylelated compound $\mathbf{1 5}$ are the products of the conversion of diazonium hydrosulfate of 1-amino-2-methyl-9,10-anthracenedione $\mathbf{1 3}$ in methanol and dioxane [4].
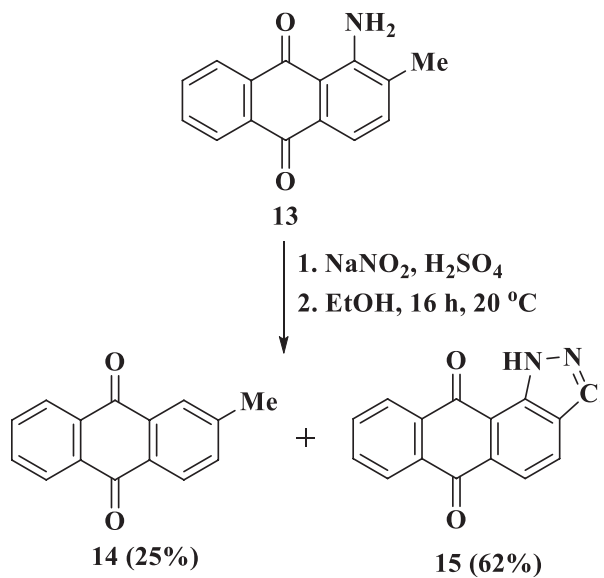

The treatment of 9,10-dioxoanthracenyldiazonium 16 chlorides with zinc dust in ethanol solution was a convenient approach to the synthesis of reduction products 17 [4]. 


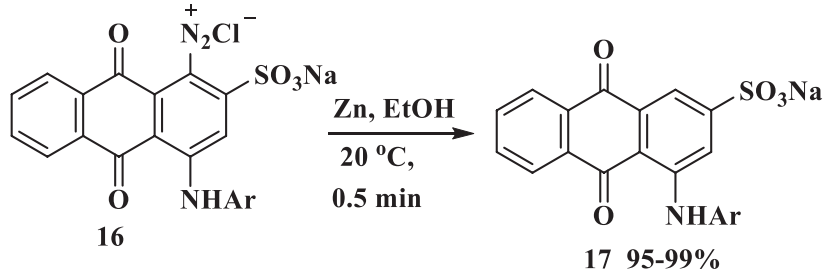

It should be noted that the introduction of the hydroxyl group, halogen atom, azide, nitrile, sulfur- and phosphorus-containing substituents by replacing the diazonium group of 9,10 -anthracenedione is widely used in synthetic practice since the early XX century [1].

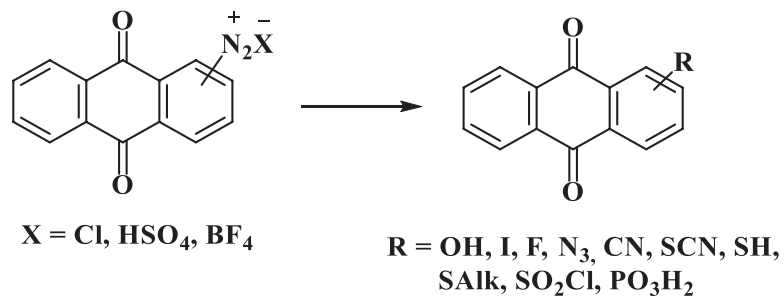

Hydroxyderivatives are easily obtained by the hydrolysis of diazonium salts of aminoanthracene-9,10-diones $[3,5,6]$. The interaction of the corresponding diazonium salt with potassium iodide at room temperature is used to obtain 1(2)-iodo-9,10-dioxoanthracene [7]. The one-step interaction of 1(2)-amino-9,10-dioxoanthracene with the diazotizing $\mathrm{NaNO}_{2}-\mathrm{HI}$ system in dimethyl sulfoxide medium allows one to obtain the target product with higher yield [8]. The corresponding 1,8-difluoro derivative 19 was obtained under the conditions of the Baltz-Schiman reaction from bis-tetrafluoroborate 9,10-dioxoanthracenyl diazonium 18.

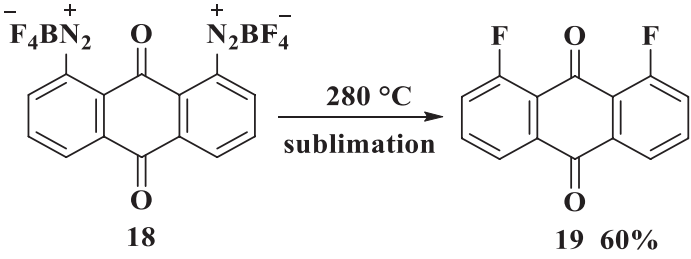

Nitrile-containing 9,10-dioxoanthracenes are usually obtained under the conditions of the Sandmeyer reaction in the presence of an aqueous solution of a complex salt of copper (I) cyanide and potassium/sodium cyanide $[1,9]$.

The formation of 1(2)-azido derivatives of 9,10 -anthracenedione easily occurs when the corresponding diazonium salts interact with sodium azide in an aqueous medium [10-12].

The synthesis of 1-mercapto-9,10-anthracenedione involves a two-stage process, in which the first stage is carried out by the thiocyanation of the diazonium salt with potassium rhodanide, and the second stage involves alkaline hydrolysis in an aqueous-ethanolic solution [1]. An alternative method of obtaining such a compound is the interaction of 9,10-dioxoanthracenyldiazonium hydrosulfate with potassium dithiocarbonate in an aqueous medium followed by hydrolysis [13].

Thiocyanate derivatives were obtained by the diazotization of 1-amino- and 1,4-diamino-9,10-dioxoanthracene with sodium nitrite in sulfuric acid, followed by the action of potassium thiocyanate $[14,15]$.

Several studies on the synthesis of 1(2)thio-containing 9,10-anthracenediones by the $S$-arylation of thioglycolic acid with diazonium salts have been described in the literature $[14,16]$. 9,10-Dihydro-9,10-dioxoanthracene2-ylsulfonyl chloride was obtained from the corresponding diazonium chloride and sulfur (IV) oxide in the presence of copper (II) chloride [17]. Phosphorus-containing derivatives based on diazonium tetrafluoroborates of 9,10 -anthracenedione are represented by (9,10-dioxo-9,10-dihydroanthracene-1(2)-yl) phosphonic acids 20, 21, which are formed by the interaction of salts $\mathbf{5 ,} \mathbf{6}$ with phosphorus (III) chloride in the presence of a salt of 
copper (I) and can be easily converted into ammonium salts $[18,19]$.

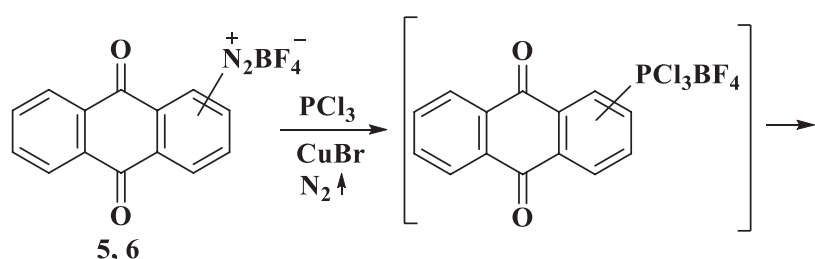<smiles>O=C1c2ccccc2C(=O)c2cc(P(=O)(O)O)ccc21</smiles>

The authors of [20] proposed an effective variant for obtaining 9,10-dioxo-anthracenyldithiocarbamates under the conditions of "green" chemistry based on 9,10-dioxoanthracenyldiazonium salts. The reaction of noncatalytic arylation with freshly obtained, neutralized with sodium carbonate, diazonium hydrosulfate salts of 1(2)-amino-9,10-anthracenediones 1, 2, 22-28 and a series of in situ generated dithiocarbamic acids with fragments of diethylamine, pyrrolidine, piperidine and morpholine in an aqueous medium under mild temperature conditions led to the preparation of carbodithioates $29 \mathbf{a}-\mathbf{v}$.

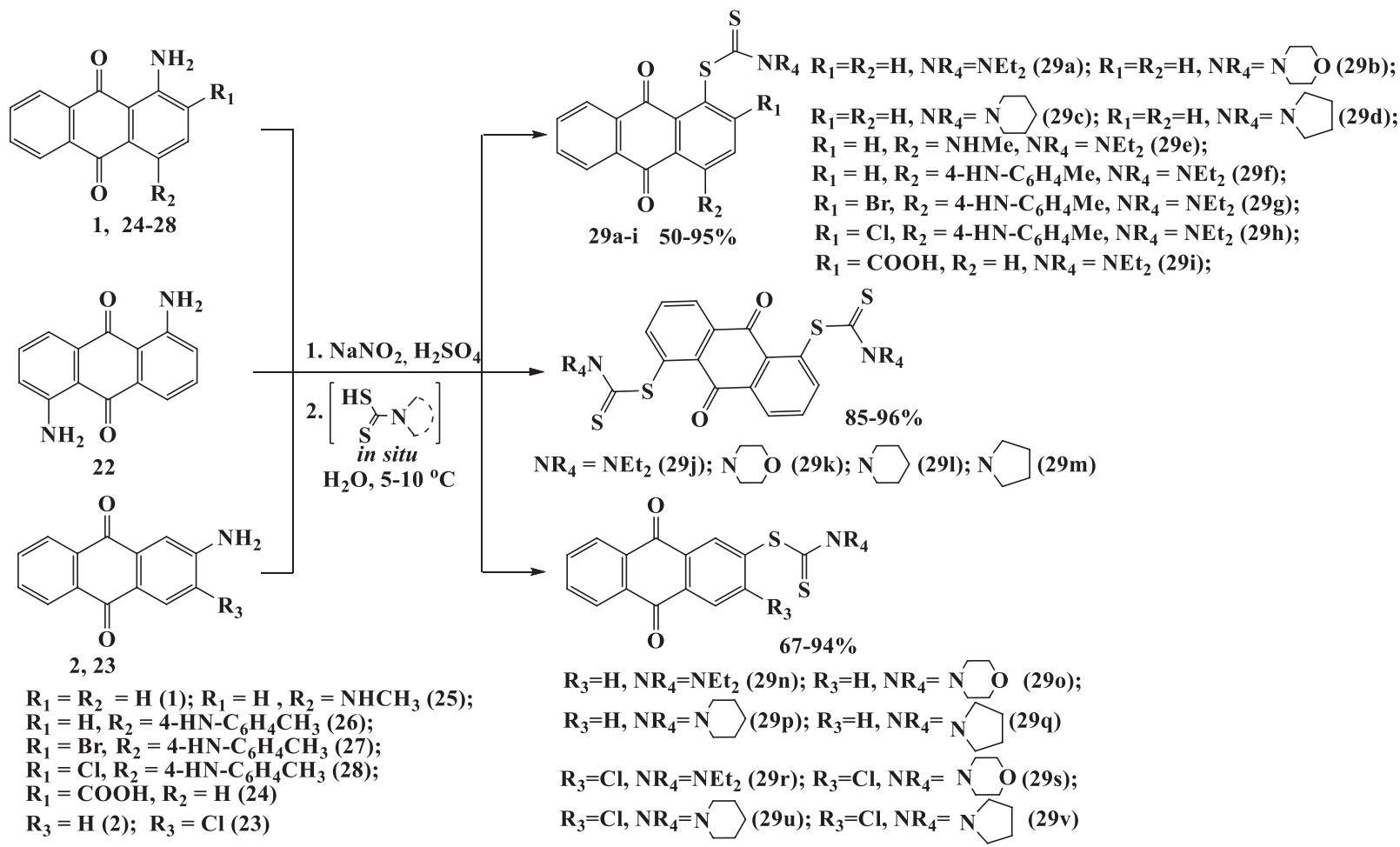


9,10-Dioxoanthracenyl-2-diazonium tetrafluoroborate 5 is a convenient reagent in the synthesis of ( $N$-Boc-3-pyrrolyl)anthracene-1-yl-9,10-dioxoanthracene 30 under the conditions of Pd-catalyzed arylation of $\mathrm{N}$-(tertbutoxycarbonyl) -3-pyrroline salt 5 [21].

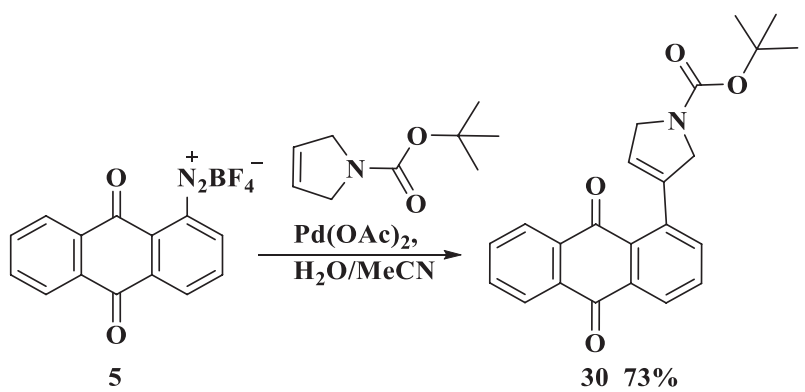

The authors of [22-28] described the use of diazonium salt 7 to obtain functional derivatives 31 in the presence of copper (II) salts.<smiles>O=C1c2ccccc2C(=O)c2c1cccc2[N+](=O)[O-]</smiles>

\section{$\stackrel{i}{\text { or } i i}$
or $i i i$}<smiles>[R]c1cccc2c1C(=O)c1ccccc1C2=O</smiles>

$31 \mathrm{R}=\mathrm{Br}, \mathrm{CH}=\mathrm{CH}_{2}$,
$i-\mathrm{CuBr}_{2}, \mathrm{MeCN}, 14 \mathrm{~h}, 20{ }^{\circ} \mathrm{C}, 70 \%$;

ii - $\mathrm{CuBr}_{2}$, MeCN, 14 h, $20^{\circ} \mathrm{C}$, TBAF, Pd(dba) 2 , 2-(di-tertbutylphosphino)biphenyl, THF, $20^{\circ} \mathrm{C} 8 \mathrm{~h}, 80^{\circ} \mathrm{C}, 96 \%$;

iii - $\mathrm{CuBr}_{2}$, MeCN, $L$-ascorbic acid, DMSO, $12 \mathrm{~h}, 20^{\circ} \mathrm{C} 70 \%$

The influence of electron-donor substituents in the fourth position of the 9,10-dioxoanthracene nucleus on the cyclization process of alkynyl-containing hydrosulfate diazonium salts 32, 35 was determined [29].

The presence of such substituents not only stabilizes the latter, but also allows the nucleophilic substitution of the diazo group with the azide anion and the conversion of compounds 33,36 to isoxazoles 34,37 without involving acetylene function.
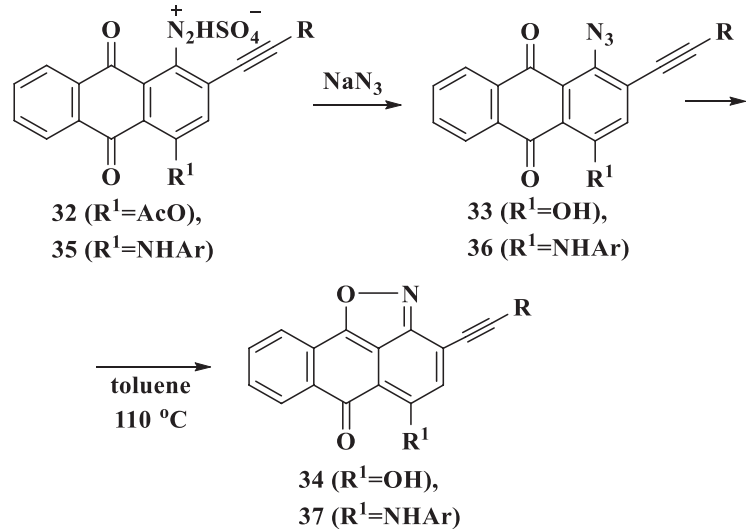

$\mathrm{R}=\mathrm{Ph}, 4-\mathrm{NO}_{2} \mathrm{Ph}$, 4-BrPh, $\mathrm{C}(\mathrm{Me})_{2} \mathrm{OH}, 4-\mathrm{CH}_{3} \mathrm{OPh}$; $\mathrm{Ar}=3-\mathrm{MePh}, 4-\mathrm{MePh}$

Azidoderivatives 39 under heating above $110^{\circ} \mathrm{C}$ were converted to compounds of isoxazole type 40 , which reacted with sulfoxide to give sulfanylideneaminoanthracene-9,10-diones 41 [30].
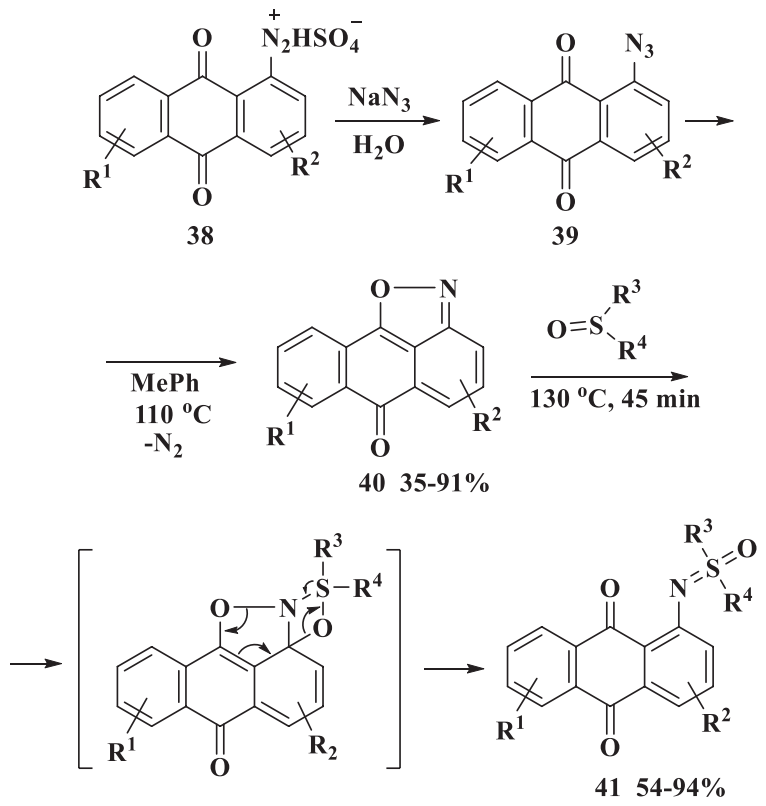

$\mathbf{R}^{1}=\mathrm{Alk}, \mathrm{R}^{2}=\mathrm{Cl}, \mathrm{NO}_{2}, \mathrm{NHC}(\mathrm{O}) \mathrm{Ph} ; \mathbf{R}^{3}=\mathrm{R}^{4}=\mathrm{Me}, \mathrm{Et}, \mathrm{Ph}$

Isoxazole derivatives $\mathbf{4 0}$ can also be used to prepare phosphoamides 42 and iminophosphoranes 43 [30]. 
<smiles></smiles>

40

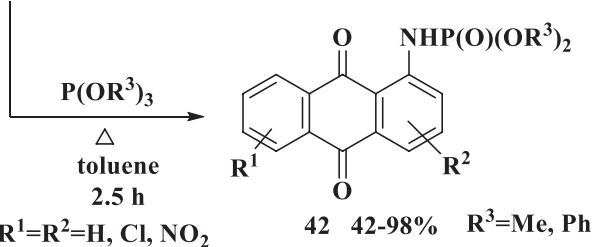

Anthra[1,9-cd:5,10-c'd']diisoxazole 46 reacts similarly with triphenylphosphine, dimethyl(diethyl, diphenyl)sulfoxides and trialkyl(aryl)oxyphosphines with the disclosure of both isoxazole cycles and the formation of corresponding bisproducts 47-49 [30].
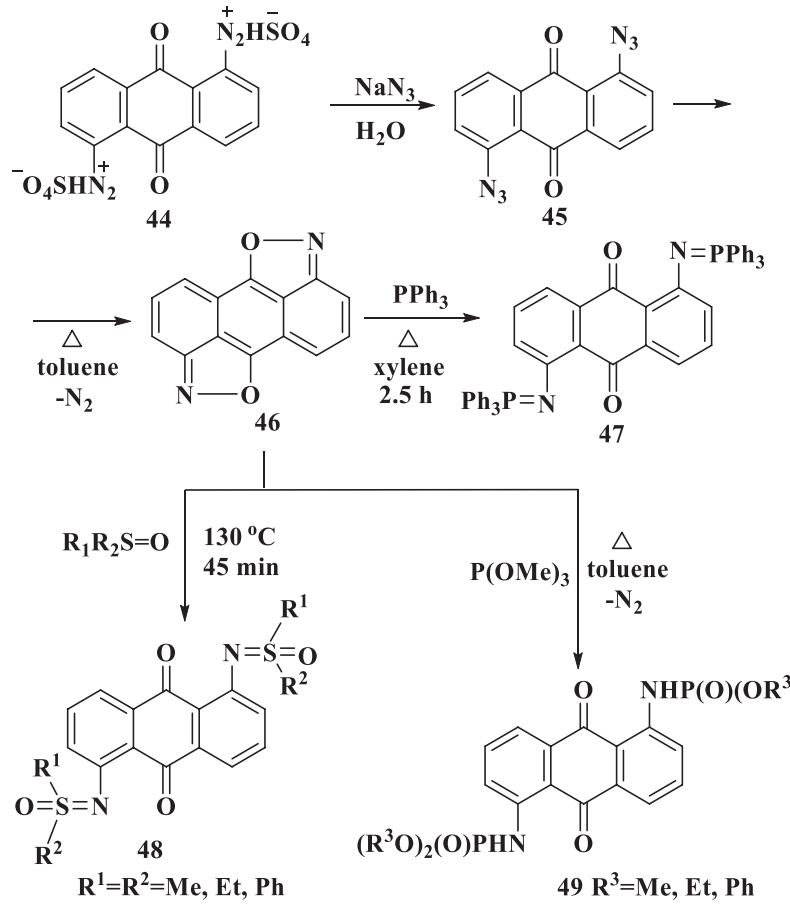

The behavior of the azides of 9,10-anthracenedione 50, 51 in the reaction of $\mathrm{Cu}-$ catalyzed 1,3-dipolar cycloaddition (CuAAC) with a number of substituted alkynes was investigated [31]. It was found that the use of systems such as CuI-L-proline in DMSO, $\mathrm{CuSO}_{4}$-potassium ascorbate in a mixture of DMF- $\mathrm{H}_{2} \mathrm{O}$ and $\mathrm{CuI}$-TEA in chloroform led to a positive result with obtaining 1,2,3-triazole derivatives $\mathbf{5 2}$ only in the case of the latter option [31].
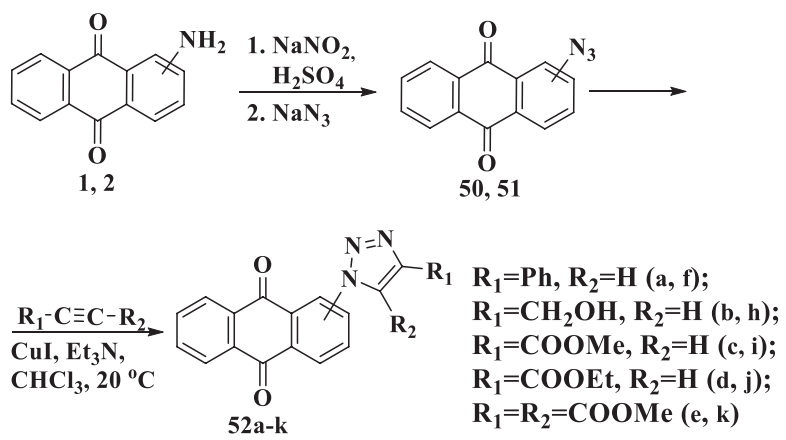

The Gomberg - Bachmann - Hay and Meerwein reactions play an important role in the transformation of the diazonium salts of 9,10-anthracenediones, since the acylation and Friedel - Crafts alkylation processes are not characteristic of 9,10-dioxoanthracene derivatives due to the effect of quinoid conjugation [32].

It was determined that the formation of the products of this reaction, aryl-9,10-dioxoanthracenes 53-60, occurs quite easily and in high yields (40-60\%). The arylation of toluene leads to the formation of 1(2)-isomers at the ortho- and para-positions to $\mathrm{CH}_{3}$-groups 57, 59 (in the case of 9,10-dioxoanthracene-1-yldiazonium) and mixtures 58, 60 (in the case of 9,10-dioxoanthracene-2-yldiazonium) [33]. 

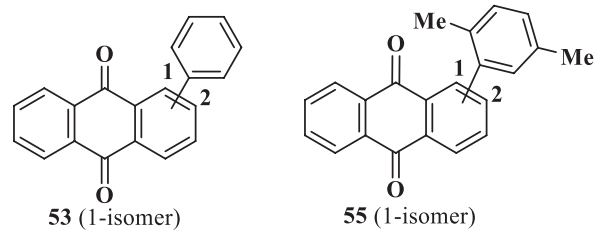

54 (2-isomer)

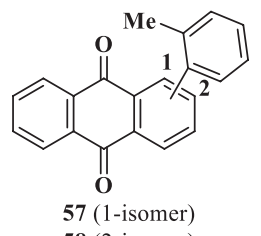

$\mathbf{5 8}$ (2-isomer)

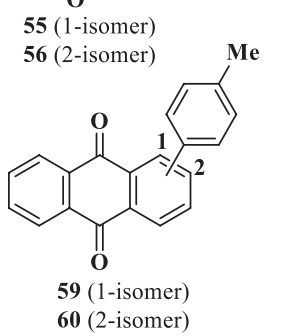

Studies of C-arylation of pyridine by diazonium salts of anthracenediones under the conditions of a modified Gomberg-BachmannHay reaction at a temperature of $-10^{\circ} \mathrm{C}$ to $70^{\circ} \mathrm{C}$ in the absence of catalyst and $\mathrm{Cu}$-catalysis have shown that a mixture of ortho-, meta- and para-products of arylation of pyridine 61-66 was the result of the interaction [34].
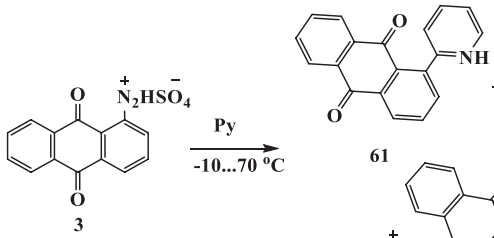

61
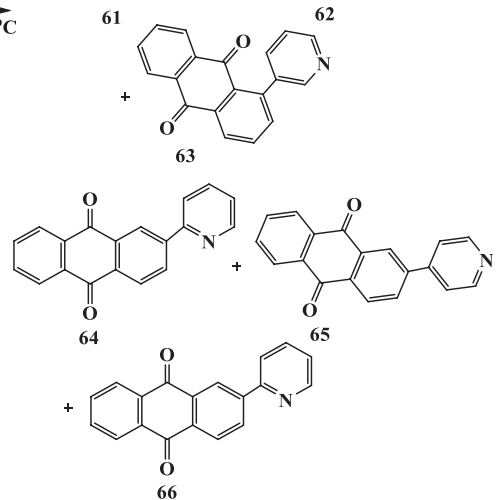

The use of Meyerwein reaction taking diazonium salts of 9,10-dioxoanthracene as an example is represented by coupling reactions with such unsaturated compounds as 1,1-dichloroethene, 1,1,2-trichloroethene, acrylic acid esters, nitrile methacrylic acid, 2,4-dicyano-1-butene in the presence of copper salts [35]. 2- (9,10-Dioxo-9,10-dihydroanthracene-
1 -yl)acetic acid 67 and its esters 68 were prepared by the $\mathrm{Cu}$-catalyzed coupling of diazonium salt 3 with 1,1-dichloroethene under mild conditions [36].

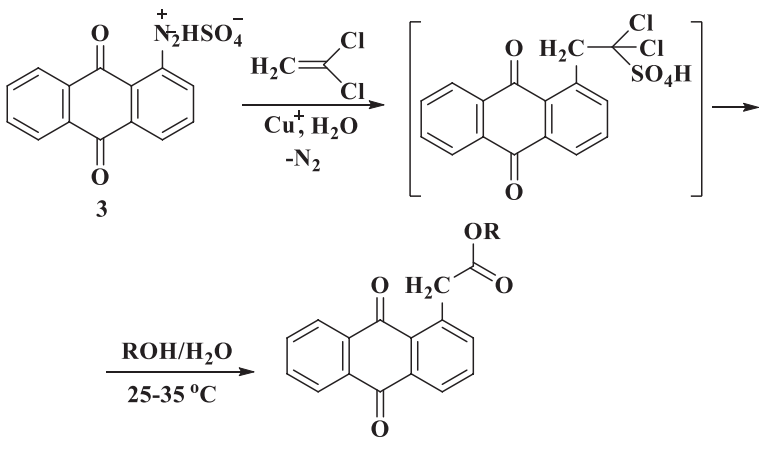

$67 \mathrm{R}=\mathrm{H}, 68 \mathrm{R}=\mathrm{C}_{1}-\mathrm{C}_{5}$ alkyl

Under similar conditions, 2-(9,10-dioxo-9,10-dihydroanthracene-1-yl)chloroacetic acid 69 was obtained in high yield from 1,1,2-trichloroethene and diazonium hydrogen sulfate 3 in acetate acid [35].<smiles>COC(=O)c1cccc2c1C(=O)c1ccccc1C2=O</smiles><smiles>[Ca][Mg]O[Ge]</smiles><smiles>O=C1c2ccccc2C(=O)c2c1cccc2C(Cl)Cl</smiles>

The authors of [35] suggested using methacrylonitrile in the presence of copper(I) chloride to obtain 1-(2-oxopropyl)anthracene-9,10-dione 70, which was converted by alkaline hydrolysis to 2-hydroxy-7H-benzo[de] anthracene-7-one $\mathbf{7 1 .}$

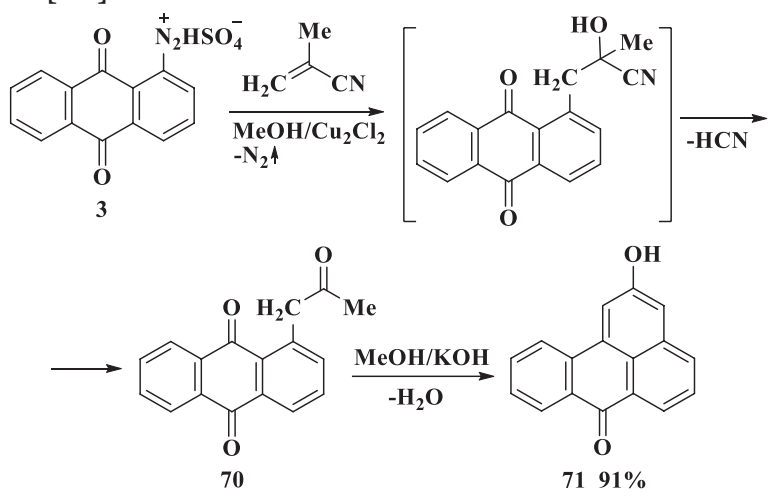


The $\mathrm{Cu}$-catalyzed arylation of 2,4-dicyano-1-butene in methanol leads to the formation of a mixture of cyanohydrin 72, cyanoketone $\mathbf{7 3}$, and 9,10-dioxoanthracene $\mathbf{7 4}$ as a dediazonation product. 5-(9,10-Dioxo-9,10dihydroanthracene-1-yl) -4-oxopentanoic acid 76 was synthesized by an acid hydrolysis of derivative 73. When methanol was replaced by acetonitrile, the formation of 2-chloro-2$[(9,10$-dioxo-9,10-dihydroanthracene-1-yl) methyl]pentanedinitrile 75 was observed as the main product [35].<smiles>N#CCCC(=O)Cc1cccc2c1c(=O)c1ccccc1c(=O)c1cccc(Br)c12</smiles><smiles>C=C(C#N)CCC#N</smiles>

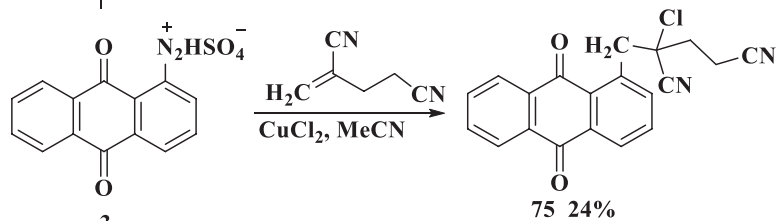<smiles>N#CCCC(=O)Cc1cccc2c1C(=O)c1ccccc1C2=O</smiles>

The authors of [2] observed the formation of $\mathrm{C}-\mathrm{C}$ coupling products 77-82 in the study of the arylation of methyl esters of acrylic and methacrylic acids, acrylamide and 1,4-benzoquinone by 9,10-anthracenedione-1-diazonium tetrafluoroborate under the conditions of Meerwein reaction.

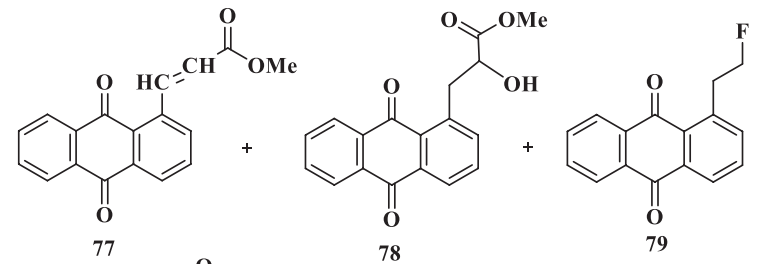

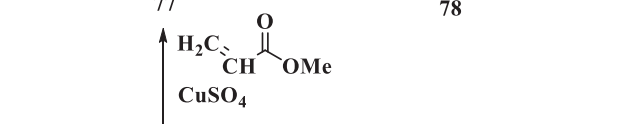

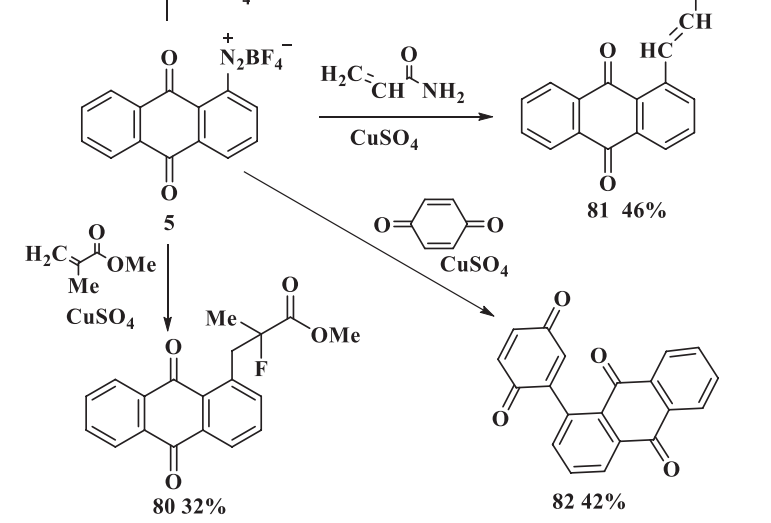

Functionalized with a methylfuran fragment, 9,10-anthracenedione derivative $\mathbf{8 3}$ was obtained under the conditions of Meerwein reaction by the arylation of diethyl 2-methylenepentanedioate in the presence of copper(I) chloride in methanol [35].

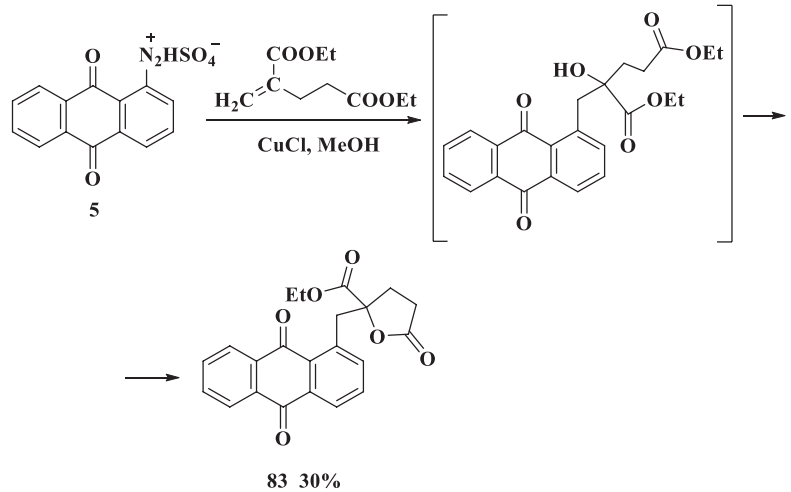

The behavior of 9,10-anthracenedione-1-diazonium chloride $\mathbf{8 4}$ was also studied under the conditions of the Meerwein reaction in the presence of $\mathrm{CuCl}_{2}$ in an acetone medium [37], and it was found that the product of this interaction is tetrachlorocuprate (II) 85 . 


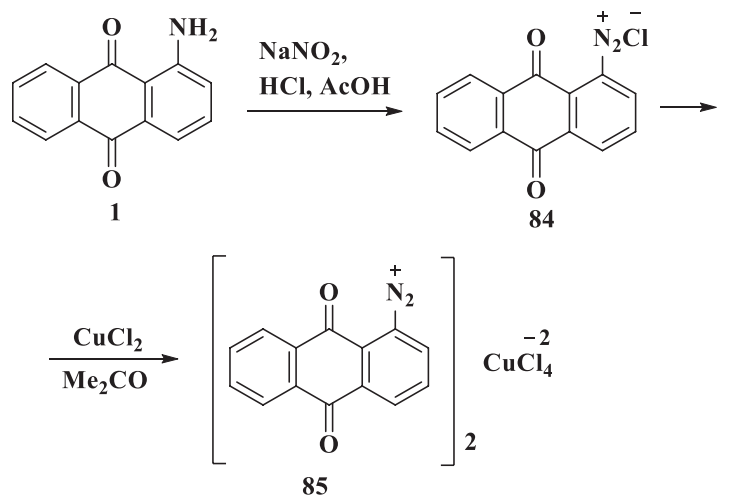

The dediazonation of tetrachlorocuprate (II) 85 in polar solvents at room temperature led to 1-chloro-9,10-anthracenediones. Instead, 9,10-anthracenedione chloro- and hydroxypropionates $\mathbf{8 6}$ were obtained in the presence of acrylate esters [37].

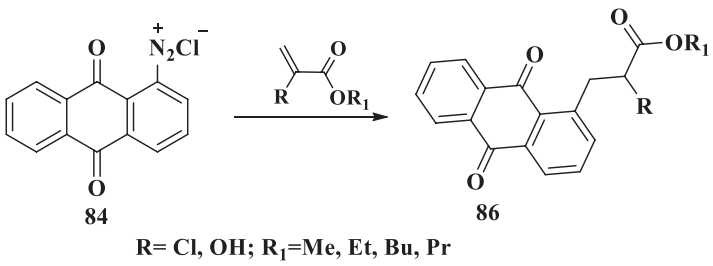

The replacement of $\mathrm{CuCl}$ by $\mathrm{FeSO}_{4}$ leads to the formation of a mixture of ketones $\mathbf{8 7}$ and $\mathbf{8 8}$, the yield of which is significantly affected by the sequence of addition of reagents [32].
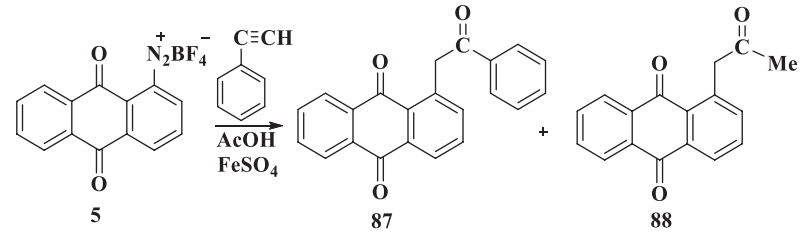

Annelated derivatives of 9,10-dioxoanthracene prepared on the basis of diazonium salts are presented in the literature by a limited number of examples. In particular, a convenient method was proposed for the preparation of benzofuran-dioxoanthracene compounds 90 by heating 4-hydroxy-9,10-dioxo-2-aryloxy-9,10-dihydroanthracene-1-diazonium salts 89 [38].

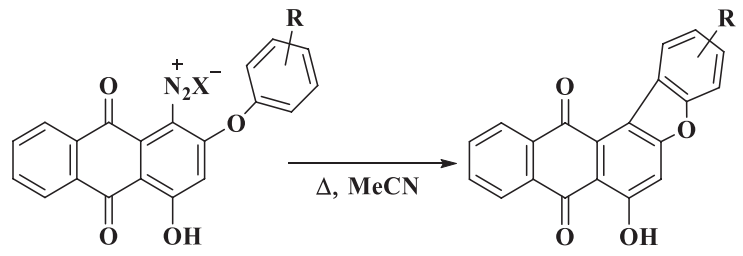

$89 \mathrm{X}_{=} \mathrm{HSO}_{4}, \mathrm{BF}_{4}, i$ - $\mathrm{PrNO}$

$90 \mathrm{R}=\mathrm{Alk}$, $\mathrm{NO}_{2}$, Hal $68-88 \%$

Moreover, benzofuran- 93 and benzothiophene-condensed derivatives 94 of 9,10-anthracenedione were obtained by the photocyclization of 1-aryloxy(arylthio)-9,10-dioxoanthracenyldiazonium chlorides $\mathbf{9 1}$ and $\mathbf{9 2}$ in dioxane or in a mixture of acetate acid with dioxane [39].

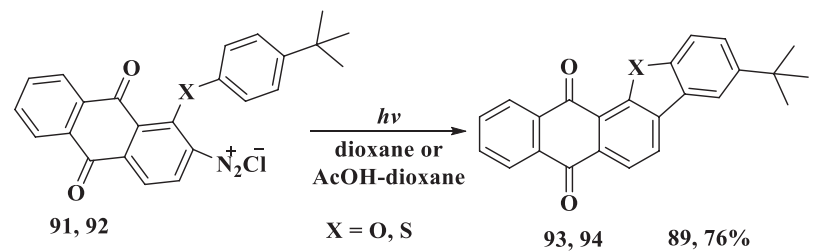

The preparation of condensed tetrahydrodipyranium derivatives 95 was described in [39], where bis(hydrosulfatediazonium) 9,10-dioxoanthracene $\mathbf{4 4}$ was used in coupling reactions with unsaturated compounds (nitriles of acrylic and methacrylic acids, methyl and ethyl esters of acrylic acid, styrene and methylstyrene) in the presence of copper(I) salts in a dimethylphosphite medium.

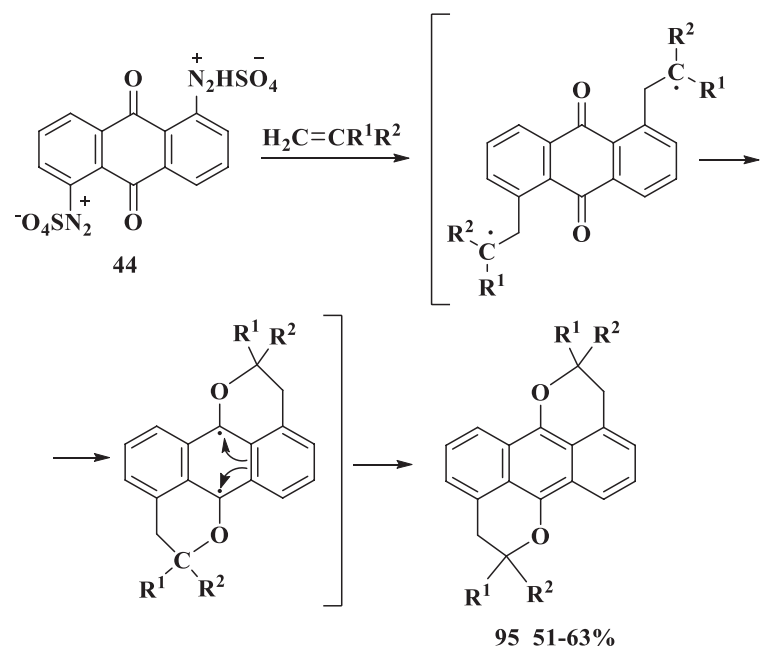

$\mathbf{R}^{1}, \mathbf{R}^{2}=\mathrm{H}, \mathrm{CN},\left(\mathrm{CH}_{2}\right)_{2}, \mathrm{CN}$, COOMe, COOEt, $\mathrm{Ph}, \mathrm{C}_{6} \mathrm{H}_{4} \mathrm{Cl}, \mathrm{COOH}$ 
REACTIONS OF DIAZONIUM SALTS OF AMINO-9,10-ANTHRACENEDIONES WITH PRESERVATION OF THE AZO FUNCTION

The azo coupling reaction of diazonium salts of 9,10-dioxoanthracene is one of the key reactions and is widely used in the production of azo dyes [40]. The property of diazotized amino-9,10-anthracenediones to form colored azo coupling products has also been used in analytical methods, in particular for the determination of ascorbic acid [41] and isoniazid [42].

A number of $\alpha$ - and $\beta$-carbonyl-containing compounds were successfully used in the modified Jappa-Klingemann reaction with 9,10-dioxoanthracenyldiazonium hydrosulfates 3 and 96 to obtain hydrazone derivatives $\mathbf{9 7}$ and 98, in which acyl and/or alkoxycarbonyl groups are present in the ylidene part of the hydrazone fragment [43]. Products 97 and 98 were easily formed with good yields in an aqueous medium by the arylation of carbonyl reagents with freshly prepared diazonium hydrosulfates 3 and 96 under mild temperature and non-base conditions.

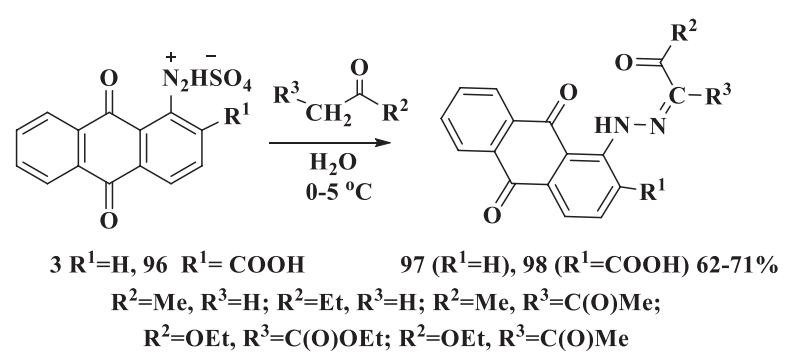

The authors in [44] proposed a method for the synthesis of indazolone derivative 99, which consisted in a sequential two-stage interaction of aminoanthracenedione $\mathbf{1}$ with 3-hydroxybenzoic acid and $p$-toluidine.

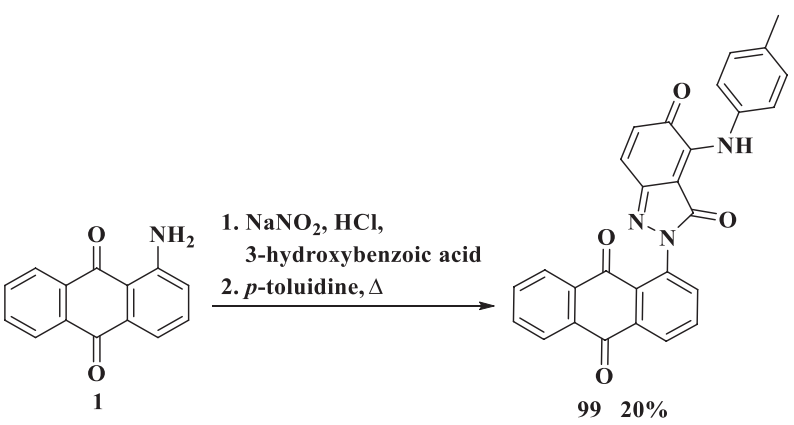

The formation of phenolic and naphthalene derivatives containing the 9,10-dioxoanthracene diazo component occurs quite easily under the conditions of azo coupling of diazonium salts with an aromatic component [45-47]. For the products of azo coupling of diazonium salts 100 with $\beta$-naphthol 101 in solutions of dimethyl sulfoxide or chloroform, a tendency to azo-hydrazone tautomerism was found as a result of the peri-effect of the carbonyl group [48].

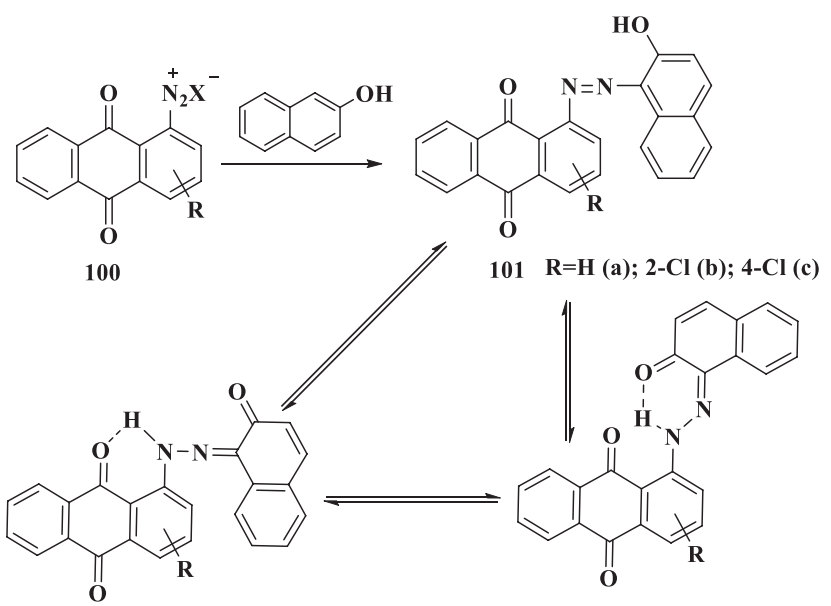

In the above mentioned work, a number of 1-arylazo-9,10-anthracenedione derivatives 103 with aminoalkyl, aminocarbocyclic and heterocyclic moieties at the position 4 were prepared in sequential reactions of azo coupling of salt $\mathbf{1 0 2}$ and nucleophilic substitution in compounds 
103 in a medium of $\mathrm{N}, \mathrm{N}$-dimethylacetamide at $50-60{ }^{\circ} \mathrm{C}$ or $\mathrm{N}, \mathrm{N}$-dimethylformamide in the temperature range of $60-80^{\circ} \mathrm{C}$.

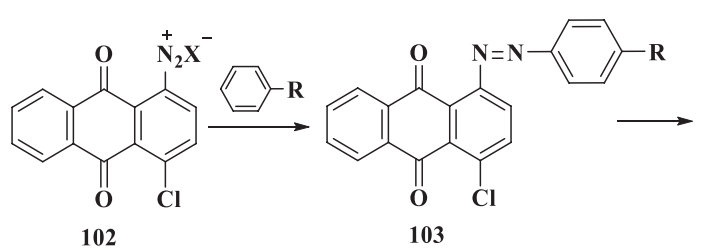

$\mathbf{R}=\mathbf{O H}, \mathbf{N}(\mathbf{M e})_{2}$

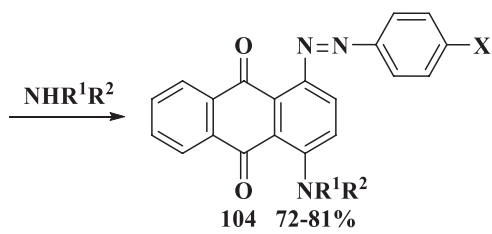

$\mathrm{NR}^{1} \mathrm{R}^{2}=\mathrm{NAlk}_{2}, \mathrm{NHAlk}, \mathrm{N}-\square, \mathrm{N}, \mathrm{N}$

As noted above, the $\mathrm{Cu}(\mathrm{I})$-catalyzed arylation of phenylacetylene by 9,10 -dioxoanthracenyldiazonium tetrafluoroborate 5 has its own specificity and can occur with the formation of various reaction products [33]. In particular, it was established that in aqueous acetone azo couplings are realized with the formation of hydrazones of derivative $\mathbf{1 0 5}$. Instead, isomeric 1-[(2-oxo-2-phenylethyl) diazenyl]anthracene-9,10-dione $\mathbf{1 0 6}$ is formed in the medium of acetic acid or dimethyl sulfoxide.

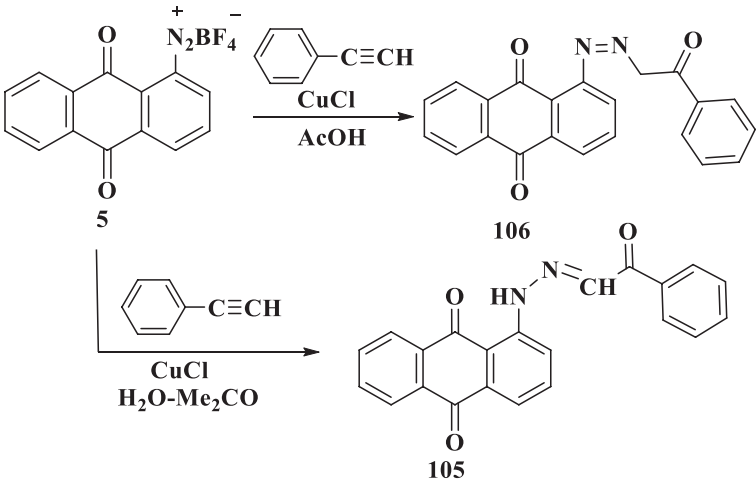

In contrast to the products of a similar reaction in DMSO [32], the arylation of styrene under conditions of a catalytic amount of iron(II) sulfate in dioxane leads to the formation of azo product 107 [33].
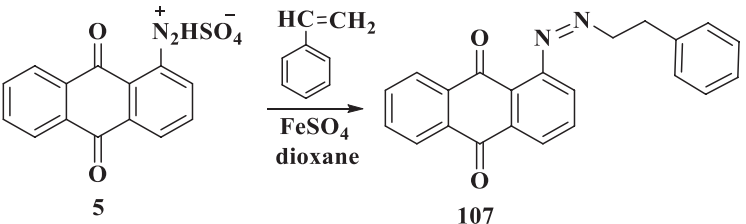

A convenient way of obtaining hybrid structures with 1,3-oxazepinedione $\mathbf{1 1 0}$ and benzo[1,3] oxazepinedione 111 cycles based on the successive transformations of azo coupling product 108 obtained with 9,10-dioxoanthracene-1-yldiazonium 84 and salicylic aldehyde has been proposed in [49].

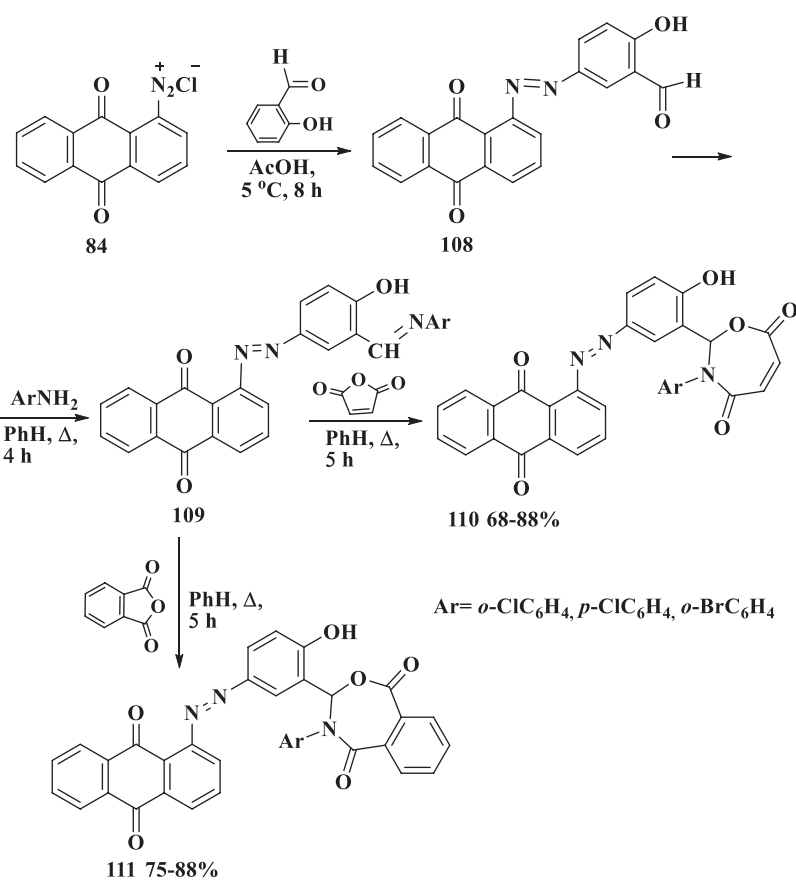

A series of 9,10-anthracenedione triazene derivatives 113 and 115 was obtained by the arylation of the corresponding arylamines and hydroxylamine substituted by salts $\mathbf{1 1 2}$ in the presence of catalytic amounts of $\mathrm{AcONa}$ in a DMF medium. The synthesized compounds 
were found to be capable of azo-hydrazone tautomerism [48].

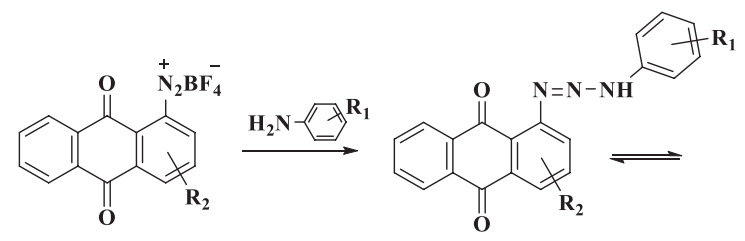

112

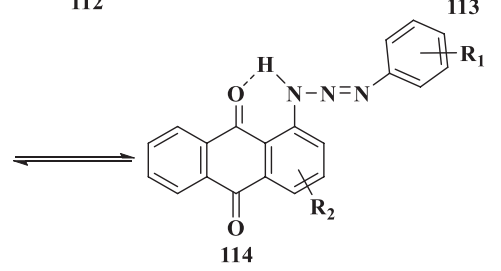

$\mathbf{R}_{1}=\mathrm{H}$, 2-Me, 3-Me, 4-Me, 2,4,6-(Me) 3 , 4-OMe, 4-OEt, 4-Cl, 3-Br, 3- $\mathrm{NO}_{2}$

$\mathbf{R}_{2}=\mathrm{H}, \mathrm{Cl}, \mathrm{OPh}, \mathrm{NHC}_{6} \mathrm{H}_{11}, \mathrm{NHPh}, 4-\mathrm{MeC}_{6} \mathrm{H}_{4} \mathrm{NH}$

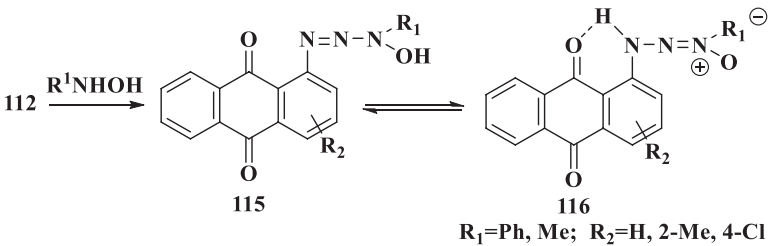

Triazene derivatives with $\mathrm{N}$-aminoalkyl fragments 117 were obtained in high yields by the azo coupling of diazonium salt 5 with a number of aliphatic amines $[10,50,51]$.

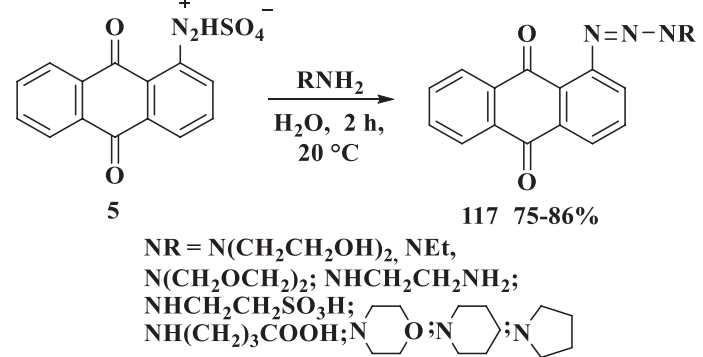

The work [48] describes the synthesis of 1-(aryltriazen)-4-substituted-9,10-dioxoanthracenes 118, which were cyclized to triazolo-anelated derivatives 119 in dimethyl sulfoxide in the presence of catalytic amounts of potassium carbonate.

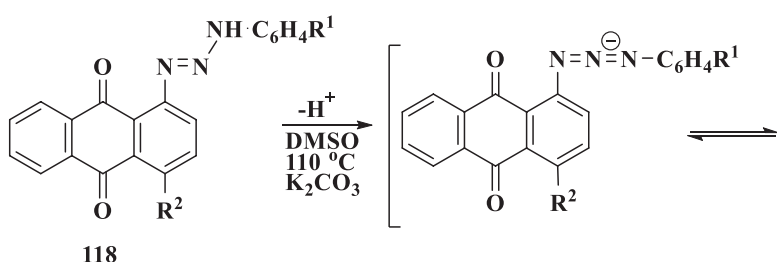

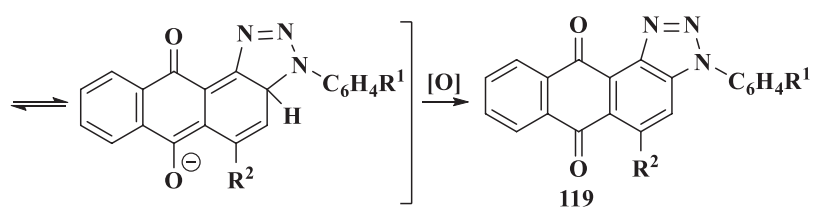

$\mathrm{R}^{1}=\mathrm{H}, 2-\mathrm{Me}, 3-\mathrm{Me}, 4-\mathrm{Me}, 4-\mathrm{OMe}, 4-\mathrm{OEt}, 3-\mathrm{Br}, 4-\mathrm{Cl}$ $\mathrm{R}_{2}=\mathrm{H}, \mathrm{Cl}, \mathrm{OPh}, \mathrm{NHC}_{6} \mathrm{H}_{11}, \mathrm{NHPh}, 4-\mathrm{MeC}_{6} \mathrm{H}_{4} \mathrm{NH}$

The diazotization of acetylene-containing 1-amino-9,10-anthracenediones $\mathbf{1 2 0}$ in the presence of hydrochloric acid leads to the formation of a mixture of annelated pyrazole derivatives 121 and 122 .
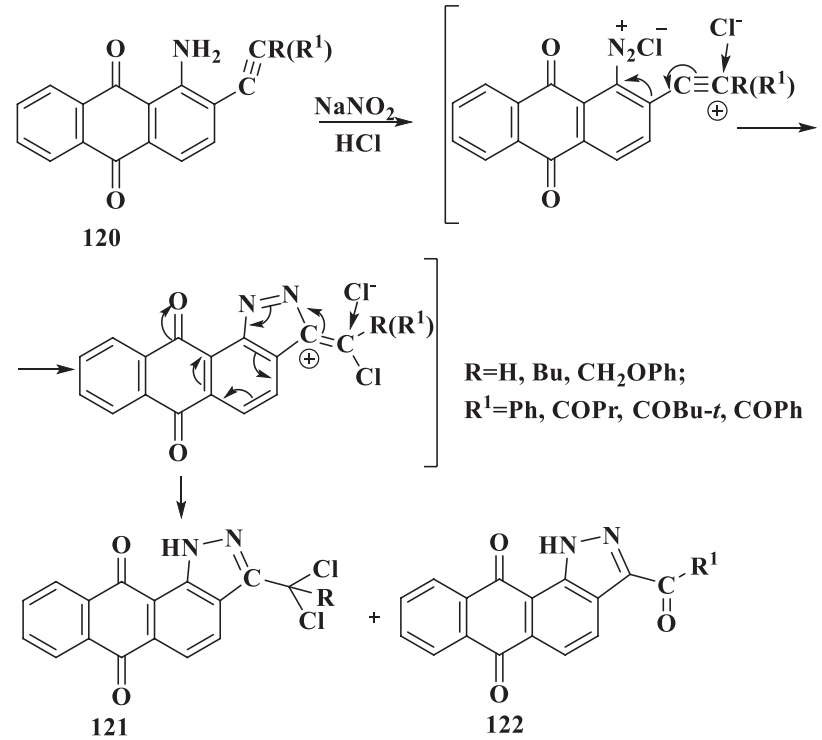

In turn, diazonium sulfates 123 intramolecularly condense under the action of sulfuric acid into naphtho[2,3- $h]$ cinoline-4,7,12- (1H)triones $124[52,53]$. 


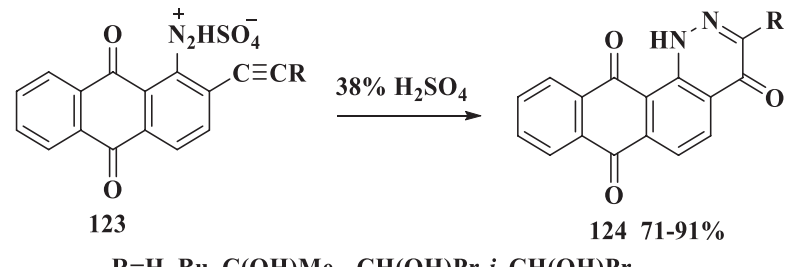

$\mathrm{R}=\mathrm{H}, \mathrm{Bu}, \mathrm{C}(\mathrm{OH}) \mathrm{Me}_{2}, \mathrm{CH}(\mathrm{OH}) \mathrm{Pr}-i, \mathrm{CH}(\mathrm{OH}) \mathrm{Pr}$

It was found that compounds $\mathbf{1 2 5}$ with the simultaneous presence of an acetyl fragment at the position 4 of the anthracenedione nucleus and of electron-donating substituents in the alkynyl fragment form cyclic derivatives $\mathbf{1 2 6}$ in excellent yields (up to 89\%) [29].

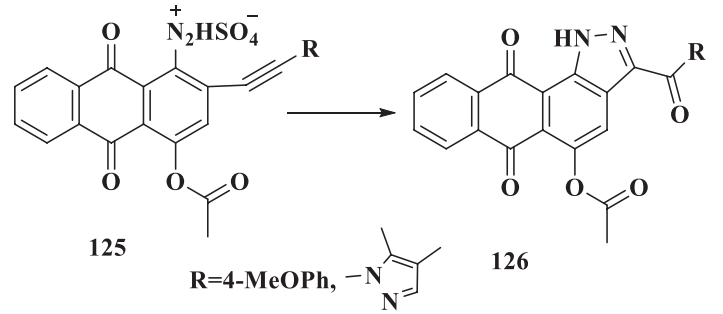

3-Phenyl-1H-naphtho[2,3-g]indazole-6,11dione 128 was formed in a fairly high yield from 1-diazonium-2-benzyl-9,10-anthracenedione sulfate $\mathbf{1 2 7}$ in ethanol [54].

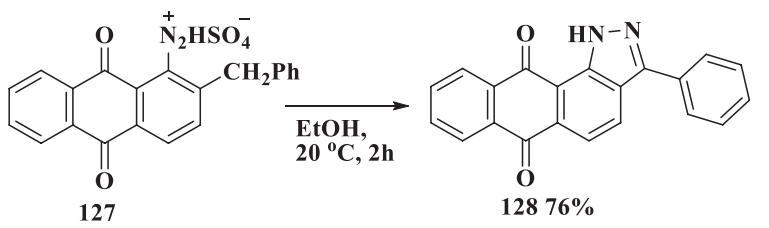

An efficient synthetic approach [55] for the preparation of a number condensed derivatives of 9,10-anthracenediones, namely anthra $[1,2-d][1,2,3]$ triazine $-4,7,12(3 H)$-triones 130, was proposed via the conditions of diazotization intramolecular cyclization reaction of 1-amino-9,10-dioxoanthracene-2-carboxamides 129.

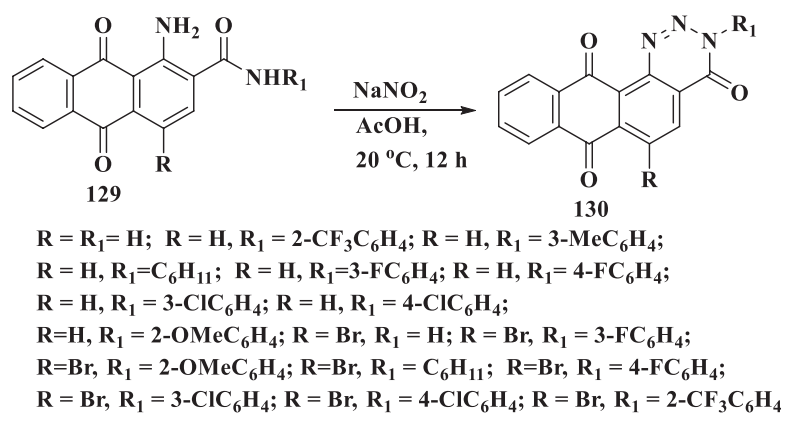

CONCLUSIONS. Thus, the presented generalized literature data on the known reactions of diazonium salts of 9,10-anthracenedione show their pronounced synthetic potential. Moreover, the preparation of derivatives according to the dediazonation scheme under the conditions of the Sandmeyer, Meerwein, Gomberg - Bachmann - Hay or azo coupling reactions is presented in most of the published works. In turn, the approach associated with the arylation of $S$-nucleophiles is less studied and is limited to the synthesis of only some of their representatives. The works devoted to the arylation of aryl alkynes, arylamines, and carbonyl-containing compounds by diazonium salts with the formation of hydrazone derivatives deserve special attention. The use of 9,10-anthracenyldiazonium salts is no less synthetically significant in the reactions of annelation of triazole, pyrazole, pyridazine and triazinone nucleus. 
СИНТЕТИЧНИЙ ПОТЕНЦІАЛ

\section{9,10-АНТРАХІНОНІЛДІАЗОНІСВИХ СОЛЕЙ}

M. В. Стасевич ${ }^{1 \star}$, B. I. Зварич ${ }^{1}$,

В. П. Новіков ${ }^{1}$, М. В. Вовк ${ }^{2}$

${ }^{1}$ Національний університет "Львівська політехніка», вул. С. Бандери, 12, Львів 79013, Україна

${ }^{2}$ Інститут органічної хімії НАН України, вул. Мурманська, 5, Київ 02660, Україна

*e-mail:maryna.v.stasevych@gmail.com

Вперше узагальнено та систематизовано літературні джерела, які стосуються хімічних перетворень діазонієвих солей 1(2)-аміно-9,10-антрацендіонів. Розкрито потенціал солей 9,10-діоксоантраценілдіазонію як ключових субстратів у процесах одержання різноманітних лінійно-функціоналізованих, ациклічних та гетероциклічних похідних. Проаналізовано основні синтетичні перетворення діазонієвих солей аміно-9,10-антрацендіонів, які реалізуються без збереження азофункції i призводять до утворення продуктів реакцій Зандмеєра, Меєрвейна та Гомберга Бахмана - Хея. Висвітлено використання солей 9,10-діоксоантраценілдіазонію або продуктів їхніх трансформацій для одержання гетерилвмісних конденсованих та функціоналізованих похідних.

Ключові слова: діазонієві солі 1(2)-аміно-9,10-антрацендіонів, дедіазоніювання, азосполучення, анелювання, гетерилфункціоналізація

\section{СИНТЕТИЧЕСКИЙ ПОТЕНЦИАЛ}

\section{9,10-АНТРАХИНОНИЛДИАЗОНИЕВЫХ СОЛЕЙ}

M. В. Стасевич ${ }^{1 *}$, В. I. Зварич В. П. Новиков ${ }^{1}$, М. В. Вовк ${ }^{2}$

${ }^{1}$ Национальный университет «Львивська политэхника», ул. С. Бандеры, 12, Львов 79013, Украина

${ }^{2}$ Институт органической химии НАН Украины, ул. Мурманская, 5, Киев 02660, Украина

*e-mail: maryna.v.stasevych@gmail.com

Впервые обобщены и систематизированы литературные источники, касающиеся химических превращений диазониевих солей 1(2)-амино-9,10-антрацендионов. Раскрыт потенциал солей 9,10-диоксоантраценилдиазония как ключевых субстратов в процессах получения различных линейно-функционализированных, ациклических и гетероциклических производных. Проанализированы основные синтетические преобразования диазониевих солей амино-9,10-антрацендионов, которые реализуются без сохранения азофункции и приводят к образованию продуктов реакций Зандмейера, Меервейна и Гомберга Бахмана - Хэя. Освещено использование солей 9,10-диоксоантраценилдиазония или продуктов их трансформации для получения гетерилсодержащих конденсированных и функционализированных производных.

Ключевые слова: диазониевые соли 1(2)амино-9,10-антрацендионов, дедиазонирование, азосочетание, аннелирование, гетерилфункционализация 


\section{REFERENCES}

1. Gorelik M.V. Chemistry of Anthraquinones and Their Derivatives. (Moscow: Chemistry, 1983. [in Russian].

2. Sweidan K., Zalloum H., Sabbah D. A., Idris G., Abudosh K., Mubarak M.S. Synthesis, characterization, and anticancer evaluation of some new $N^{1}$-(anthraquinon2-yl)amidrazone derivatives. Canadian Journal of Chemistry. 2018. 96: 1123.

3. Denisov V.Ya., Tkachenko T.B. Investigation of the reactions of anthraquinonyl diazonium salts. Izvestiya Vysshikh Uchebnykh Zavedenii, Seriya "Khimiya I Khimicheskaya Tekhnologiya”. 2005. 48: 99.

4. Baqi Y., Müller C.E. Efficient and mild deamination procedure for 1-aminoanthraquinones yielding a diverse library of novel derivatives with potential biological activity. Tetrahedron Letters. 2012. 53: 6739.

5. Rochlin E., Rappoport Z. Stable simple enols. resolution of chiral 1-[9'-(2'-fluoroanthryl)]-2,2-dimesitylethenol. A different racemization mechanism for the enol and its acetate. Journal of Organic Chemistry. 2003. 68: 216.

6. Proctor C.J., Kralj B., Larka E.A., Porter C.J., Maquestiau A., Beynon J.H. Studies of consecutive reactions of quinones in a reversed geometry mass spectrometer. Organic Mass Spectrometry. 1981. 16: 312.

7. Shao M., Chen G., Zhao Y. Synthesis and electronic properties of a conjugated ttfaq trimer and donor-acceptor ensembles of TTFAQ and anthraquinone. Synlett. 2008. 3: 371 .

8. Baik W., Luan W.Q., Lee H.J., Yoon C.H., Koo S., Kim B.H. Efficient one-pot transformation of aminoarenes to haloarenes using halodimethylisulfonium halides generated in situ. Canadian Journal of Chemistry. 2005. 83: 213.

9. Willem F., van der Schalk U. Über anthrachinon-carbonsäure. Chemische Berichte. 1911. 44: 128.

10. Iden H., Fontaine F.-G., Morin J.-F. Synthesis and complexation study of new ExTTF-based hosts for fullerenes. Organic \& Biomolecular Chemistry. 2014. 12: 4117.

11. Dyall L.K. Pyrolysis of aryl azides. IV. Neighbouring group effects by ortho carbonyl groups. Australian Journal of Chemistry. 1977. 30: 2669.

12. Mullock E.B., Suschitzky H. Syntheses of heterocyclic compounds, part XXI. Oxazoles from pyrolysis of aryl and heterocyclic azides in a mixture of acetic and polyphosphoric acid. Journal of the Chemical Society C: Organic. 1968. 0: 1937.

13. Verfahren zur darstellung von mercaptanen der anthrachinonreibe. German Patent DE241985, December 6, 1908.

14. Gattermann L. Die mercaptane des anthrachinons. Justus Liebigs Annalen der Chemie. 1912. 393: 113.

15. Shah M.K., Shah M.K., Shah K.H. Thiocyanation of 1-aminoanthraquinones. Indian Journal of Chemistry. 1976. 14B (8): 625.

16. Reid E.E., Mackall C.M., Miller G.E. Derivatives of anthraquinone. Aliphatic thio-ethers, dithio-ethers, and thio-ether sulfonic acids. Journal of the American Chemical Society. 1921. 43: 2104.

17. Ikemoto N., Liu J.C., Brands K.M.J., McNamara J.M., Reider P.J. Practical routes to the triarylsulfonyl chloride intermediate of a $\beta 3$ adrenergic receptor agonist. Tetrahedron. 2003. 59: 1317. 
18. Lukin A.M., Petrova G.S. On the synthesis of anthraquinone-1-arsonic 1-phosphonic acids by the diazomethod. Zhurnal obshchey khimii. 1957, 27, 2171.

19. Sabadakh O.P., Rev'yuk A.R., Taras T.M., Bolibrukh L.D. Synthesis of Antrachinonphosphonic Acids. Visnyk Natsional'noho universytetu "L'vivs'ka politekhnika», seriya Khimiya, tekhnolohiya rechovyn ta yikh zastosuvannya. 2008. 609: 145.

20. Zvarych V., Stasevych M., Lunin V., Deniz N.G., Sayil C., Ozyurek M., Guclu K., Vovk M., Novikov V. Synthesis and investigation of antioxidant activity of the dithiocarbamates derivatives of 9,10-anthracenedione. Monatshefte für Chemie. 2016. 147: 2093.

21. Antonio C.B., de Oca M., Correia, C.R.D. Synthesis of aryl pyrrolizidines from endocyclic enecarbamates. Novel applications of the Heck arylation of 3-pyrrolines using diazonium salts. ARKIVOC. 2003, x: 390.

22. Haeupler B., Burges R., Janoschka T., Jaehnert T., Wild A., Schubert U.S. PolyTCAQ in organic batteries: enhanced capacity at constant cell potential using two-electron-redox-reactions. Journal of Materials Chemistry A. 2014. 2: 8999.

23. Coleman R.S., Mortensen M.A. Stereocontrolled synthesis of anthracene $\beta$-C-ribosides: fluorescent probes for photophysical studies of DNA. Tetrahedron Letters. 2003. 44: 1215.

24. Phanstiel O. IV. Fluorescent cytotoxic compounds specific for the cellular polyamine transport system. U.S. Patent 8,410,311, April 2, 2013.

25. Lee K.-H., Kim M.-K., Yang G.-S. Condensed-cyclic compound and organic light emitting diode having organic layer includ- ing the same. U.S. Patent 20110031484, February 10, 2011.

26. Nomura H., Kawakami S., Ohsawa N., Suzuki T. Anthracene derivatives and light-emitting devices using the anthracene derivatives. U.S. Patent 2009004506, January 1, 2009.

27. Crisostomo F.P., Martin T., Carrillo R. Ascorbic acid as an initiator for the direct $\mathrm{C}-\mathrm{H}$ arylation of (hetero)arenes with anilines nitrosated in situ. Angewandte Chemie International Edition. 2014. 53: 2181.

28. Crisostomo F.P., Martin T., Carrillo R. Ascorbic acid as an initiator for the direct $\mathrm{C}-\mathrm{H}$ arylation of (hetero)arenes with anilines nitrosated in situ. Angewandte Chemie. 2014. 126: 2213.

29. Stepanov A.A., Gornostaev L.M., Vasilevsky S.F., Arnold E.V., Mamatyuk V.I., Fadeev D.S., Gold B., Alabugin I.V. Chameleonic reactivity of vicinal diazonium salt of acetylenyl-9,10-anthraquinones: synthetic application toward two heterocyclic targets. Journal of Organic Chemistry. 2011. 76: 8737.

30. Sutter P., Weis C.D. Ring opening reactions of $6 \mathrm{H}$-anthra[1,9-cd] isoxazol-6-ones and related compounds. Journal of Heterocyclic Chemistry. 1982. 19: 997.

31. Stasevych M., Zvarych V., Lunin V., Vovk M., Novikov V. The new 1,2,3-triazolylantracene-9,10-diones: synthesis and computer bioactivity screening. Chemistry \& Chemical Technology. 2017. 11: 1.

32. Tkachenko TB, Stepanova E.Yu. Investigation of the interaction of 1-anthraquinonyldiazonium salts with phenylacetylene and styrene. Vestnik Kemerovskogo gosudarstvennogo universiteta. 2008. 2: 227.

33. Tkachenko T.B. The reactions of aminoan- 
thraquinones of anthraquinonyl diazonium salts, accompanied by a complication of the carbon skeleton. Abstract of the dissertation for the degree of candidate of chemical sciences: specialty 02.00.03 "Organic chemistry". Kemerovo State University, Tomsk, 2005.

34. Stasevych M.V., Zvarych V.I., Lunin V.V., Kopak N.A., Novikov V.P., Chernobaev I.I., Vovk M.V. Arylation of pyridine with 9,10-dioxoanthracenyl-1(2)-diazonium hydrosulfates. Russian Journal of General Chemistry. 2018. 88: 836.

35. Weis C.D. Meerwein arylation reactions of olefins with anthraquinone diazonium hydrogen sulfates: formation of new carbon bonds at the carbon atoms C-1 and at C-1,5 of the anthraquinone system. Dyes and Pigments. 1988. 9(1): 1.

36. Ribaldone G., Borsotti G. Process for preparing antraquinone-1-acetic acid and esters thereof. U.S. Patent 3,891,650, June 24, 1975.

37. Obushak N.D., Lyakhovich M.B., Fedorovich I.S., Ganushchak N.I. 1-Anthraquinonediazonium tetrachlorocuprate(II) and its dediazotization. Russian Journal of Organic Chemistry. 1997. 33: 345.

38. Gornostaev L. M., Arnold E.V., Lykova E. V., Sadoschenko M.V. Synthesis and functionalization of 7-hydroxyanthra[2,1-b] benzo $[d]$ furan-8,13-diones. Chemistry of Heterocyclic Compounds. 2010. 6: 665.

39. Klimenko L.S., Mainagashev I.Ya., Fokin E.P. Photochemical and thermal transformations of diazo derivatives of 1-aryloxy- and 1-arylthio-2-aminoanthraquinones. Bulletin of the Russian Academy of Sciences, Division of chemical science. 1992. 41: 459.
40. Bien H.-S., Stawitz J., Wunderlich K. Anthraquinone Dyes and Intermediates. In Ullmann's Encyclopedia of Industrial Chemistry, $6^{\text {th }}$ ed., Ed. Kellersohn T. (Weinheim, Germany: Wiley-VCH Verlag Gmbh, 2003).

41. de Pieri Troiani E., Faria R.C. Cathodically pretreated poly(1-aminoanthraquinone)modified electrode for determination of ascorbic acid, dopamine, and uric acid. Journal of Applied Electrochemistry. 2013. 43: 919.

42. Mahfouz N.M.A., Emara K.M. Colorimetric determination of isoniazid and its pharmaceutical formulations. Talanta. 1993. 40: 1023.

43. Stasevych M., Zvarych V., Lunin V., Kopak N., Komarovska-Porokhnyavets O., Deniz N.G., Sayil C., Ozyurek, M., Guclu, K., Vovk M., Novikov V. Synthesis, investigation of antimicrobial and antioxidant activity of anthraquinonylhydrazones. Monatshefte für Chemie. 2018. 149: 1111.

44. Brass K., Albrecht F. Zur Kenntnis der Diazide des Anthrachinons. Chemische Berichte. 1928. 61: 983.

45. Hai-Ying L., Liang-Cai L. The synthesis and structure characteristics of two novel azo-quinone derivatives. Synthetic Communications. 2001. 31: 155.

46. Saika T., Iyoda T., Honda K., Shimidzu T. Multi-mode chemical transducers. Part 2. Electrochromic and photochromic properties of azoquinone compounds. Journal of the Chemical Society, Perkin Transactions 2. 1993. 6: 1181.

47. Sakilidi V.T., Bulgakova N.A., Gornostaev L.M., Taigunova V.S. Structure of diazo coupling products of anthraquinone-1-diazonium salts with 2,6-di-tert-butylphenol 
and $\beta$-naphthol. Russian Journal of Organic Chemistry. 2000. 36: 1485.

48. Bulgakova N. A. Synthesis, structure and properties of some derivatives of 9,10-anthraquinone containing a nitrogen-nitrogen bond. Abstract of the dissertation for the degree of candidate of chemical sciences: specialty 02.00.03 "Organic Chemistry", Krasnoyarsk State Pedagogical University, Krasnoyarsk, 2002.

49. Khan A.K., Raoof I.B., Essa H. J. Synthesis, characterization of some new azo compounds containing 1,3-oxazepine, anthraquinone moieties and studying their activity against pathogenic bacteria. Journal of Natural Sciences Research. 2015. 5(22): 69.

50. Sabadakh O.P., Moklyak M.G., Luchkevich E.R., Taras T.M., Bolibrukh L.D., Gubitska I.I. Selection of conditions for the synthesis of triazines of the anthraquinone series. Visnyk Natsional'noho universytetu "L'vivs'ka politekhnika», seriya Khimiya, tekhnolohiya rechovyn ta yikh zastosuvannya. 2014. 787: 249.

51. Sabadakh O.P., Taras T.N., Luchkevich E.R., Novikov V.P. Synthesis of triazene derivatives of 9,10-anthraquinone. Russian
Journal of Organic Chemistry. 2015. 51: 277.

52. Fedenok L.G., Barabanov I.I., Zolnikova N.A., Bashurova V.S., Bogdanchikov G.A. Mechanism and synthesis potentialities of the cyclization of vic-(alkynyl)arenediazonium salts. Chemistry for Sustainable Development. 2011. 19: 647.

53. Fedenok L.G., Barabanov I.I., Bashurova V.S., Bogdanchikov G.A. Mechanism of the heterocyclization of vic-alkynylanthra- and vic-alkynylnaphthoquinone diazonium salts. Tetrahedron. 2004. 60: 2137.

54. Denisov V. Ya., Tkachenko TB Studies of reactions of salts of anthraquinonyl diazonium. Izvestiya Vysshikh Uchebnykh Zavedenii, Seriya "Khimiya I Khimicheskaya Tekhnologiya”. 2005. 48: 99.

55. Zvarych V., Stasevych M., Novikov V., Rusanov E., Vovk M., Szweda P., Grecka K., Milewski S. Anthra[1,2-d][1,2,3]triazine$4,7,12(3 \mathrm{H})$-triones as a new class of antistaphylococcal agents: synthesis and biological evaluation. Molecules. 2019. 24: 4581. 